\title{
A COMBINED EFFECT OF PSEUDORABIES VIRUS GROWTH FACTOR /PRGF/ AND VARIOUS CYTOSTATICS ON TUMOUR /Hep - 2/ CELLS IN VITRO
}

\author{
P. KOCÁKOVÁ ${ }^{1}$, J. LEŠKO, K. HORÁKOVÁ ${ }^{3}$, F. GOLAIS ${ }^{1 *}$ \\ ${ }^{I}$ Comenius University, Department of Microbiology and Virology, Bratislava, \\ ${ }^{2}$ Institute of Virology, Slovak Academy of Sciences, Bratislava, ${ }^{3}$ Slovak Technical University, \\ Department of Microbiology, Biochemistry and Biology, Bratislava, Slovak Republic
}

Received April 3, 1997

Accepted November 4, 1997

\begin{abstract}
Kocáková P., J. Leško, K. Horáková, F. Golais: A Combined Effect of Pseudorabies Virus Growth Factor (PRGF) and Various Cytostatics on Tumour (Hep-2) Cells in vitro. Acta vet. Brno 1997, 66:159-169.

One of the activities of pseudorabies virus /PRV/ growth factor/PRGF/ is its ability to change the transformed phenotype of cultured tumour cells to the normal one.This activity of PRGF was studied in combination with antiproliferative activity of various cytostatics. An undesirable outcome was observed, when PRGF was combined with 11 out of 12 cytostatics. These cytostatics suppressed the ability of PRGF to change the transformed phenotype of Hep-2 cells, and on the other hand, PRGF diminished the effect of these cytostatics on growth and metabolism (DNA and protein content, glucose consumption, lactate and ammonia production) compared to non-treated control cells. This effect was not observed when the cells were cultured in the presence of PRGF and methotrexate (MTX). In this case both suppression of transformed phenotype and inhibition of cell growth were observed. Taking these results into account, PRGF combined with MTX is discussed as a possible method for cancer studies.
\end{abstract}

Pseudorabies virus growth factor, cytostatics, transformed phenotype, cell proliferation

Pseudorabies virus growth factor (PRGF) was detected in our laboratory in some virus infected or transformed cells. This factor has been shown to have two effects on cultured cells in vitro. Normal, non-transformed cells, when cultured in the presence of PRGF acquired the appearance of transformed cells (criss-cross morphology and anchorage independent growth). However, the phenotype of transformed cells cultured with PRGF became converted towards the normal one (Golais et al. 1990; Golais et al. 1992; Dušinská et al. 1994). In this paper, the effect of PRGF on morphology, growth and metabolism of human carcinoma (Hep-2) cells was studied along with 12 cytostatics in attempts to find an appropriate combination for a possible cancer treatment.

\section{Materials and Methods}

\section{Preparation of PRGF}

Non resolved PRGF ( $\mathrm{G}$ a šperík et al. 1994) was used. Monkey kidney (MK-2) cells grown in Eagle's basal medium (BEM) with $5 \%$ heated bovine serum, were infected with TOP strain of PRV at input multiplicity of $1 \mathrm{PFU} / \mathrm{cell}$. To remove the virus, the medium from infected cultures was harvested 3 days p.i. acidified to $\mathrm{pH} 3$, kept for 3 days at $4{ }^{\circ} \mathrm{C}$ and then raised again to neutrality (pH 7.2). Five $\mathrm{ml}$ aliquots of the medium were then lyophilized, resuspended in $0.5 \mathrm{ml}$ phosphate buffer $(\mathrm{pH} 7.2)$ and applied to a column $(3,5 \times 40 \mathrm{~cm})$ of Sephadex $\mathrm{G} 15$. The column was washed with deionized water at a constant flow rate $1 \mathrm{ml} / \mathrm{min}$. The samples from the column collected in $5 \mathrm{ml}$ aliquots were tested in MK-2 cells for transforming and in Hep-2 cells for transformed phenotype repressing activity (for details see $\mathrm{Gol}$ a is et al.1990). Positive samples were lyophilized, resuspended in $0.2 \mathrm{ml}$ deionized water and applied onto column of Sephadex G 75 .

The column $(3 \times 30 \mathrm{~cm})$ was washed with deionized water at a constant flow rate $0.2 \mathrm{ml} / \mathrm{min}$. Collected samples in amounts of $1 \mathrm{ml}$ were tested again in MK-2 and Hep-2 cells. Positive samles were pooled, lyophilized, resuspended in $0.5 \mathrm{ml}$ deionized water and concentrated on the Biogel P 20 column. The separation pattern on 
Sephadex G 15 and Biogel P 20 columns have been given in G o l a is et al. (1992). Biogel P 20 concentrated PRGF samples served as stocks for other studies.

Cultivation of cells in the presence of PRGF and cytostatics

Hep- 2 cells were seeded into $25 \mathrm{~cm} 2 / 50 \mathrm{ml}$ plastic NUCLON bottles $\left(2.5-3 \times 10^{5}\right.$ cells per bottle $)$ and cultivated for $24 \mathrm{~h}$ in BEM containing $5 \%$ heated bovine serum, glucose $(1 \mathrm{~g} / \mathrm{L})$ and glutamine $(300 \mathrm{mg} / \mathrm{L})$. Afterwards, the medium was removed and replaced with the same medium containing cytostatics in chosen concentrations (see Table 1) and $10^{-1}$ PRGF units /ml (for definition of one PRGF unit see Golais et al. 1992). A part of cultures received medium containing cytostatics without PRGF, or medium with PRGF without cytostatics. Control cells received intact medium without cytostatics and PRGF. 6-thioquanine (6-TG) as recommended ( Tidd et al. 1972) was removed following $24 \mathrm{~h}$ incubation and replaced with normal medium.

Table 1

\section{Cytostatics used in combination with PRGF}

\begin{tabular}{|l|l|c|}
\hline \multicolumn{2}{|c|}{ Drug } & Producer \\
\hline \multicolumn{2}{|c|}{} & \multicolumn{1}{c|}{ Optimal concentration } \\
\hline Carboplatin & Lachema & 200 \\
\hline Doxorubicin & Lemery & 90 \\
\hline 6-Thioquannine (6-TG) & Sigma & 2 \\
\hline Cytosar (Cytarabine) & Upjohn & 50 \\
\hline Fluoro-uracil & Roche & 70 \\
\hline Ifosfamid & Asta & 380 \\
\hline Ethyl-isothiocyanatobutanoate (E-4 IB)* & STU & 1,5 \\
\hline Uromitexan & Asta & 300 \\
\hline Vincristine & Lemery & 6 \\
\hline Taxol & Bristol Mayers Squibb & 5 \\
\hline Etoposide & Pierre Fabre & 5 \\
\hline Methotrexate & Ebewe & 5,5 \\
\hline
\end{tabular}

*E-4 IB was synthetized by Floch and Kovác (1975), and an antiproliferative activity of this compound was demonstrated by Horáková et al. (1993).

Cells cultured for $24 \mathrm{~h}$ in the presence of PRGF and 6-TG received only PRGF following 6-TG removal. To maintain equal initial conditions ( $\mathrm{pH}$, serum and glucose content etc.) in all cultures, the media of other samples were changed along with those containing 6-TG, however, the cytostatics were added again. All cultures were then cultivated for 3 days at $37^{\circ} \mathrm{C}$ before tested for DNA and protein content as well as for glucose consumption and production of ammonia and lactate.

To test the anchorage independent growth of cells cultured in the presence of PRGF and cytostatics, $0.5 \mathrm{ml}$ aliquots of $0.7 \%$ agar (DIFCO) in Earle's medium with $5 \%$ heated fetal bovine serum were dispensed into $2 \mathrm{~cm}^{2}$ wells of flat-bottom plates (NUCLON) and overlayed with $0.5 \mathrm{ml}$ aliquots of $0.35 \%$ agar in the same medium containing $2 \times 10^{-4}$ Hep- 2 cells. Both agar layers contained either PRGF itself $\left(1 \times 10^{-4}\right.$ unit $\left./ \mathrm{ml}\right)$, or combined with cytostatics in concentrations given in Table 1. Control wells contained cells cultivated in agar without PRGF and cytostatics. The cells cultivated at $37^{\circ} \mathrm{C}$ were controlled after 18 days for formation of colonies.

\section{Growth curves}

The cells cultivated in $25 \mathrm{~cm}^{2} / 50 \mathrm{ml}$ NUCLON bottles were trypsinized at 24 hrs intervals using ,dry“ trypsinization method ( $\mathrm{Hayflick}$ and Moorhead 1961), resuspended in equal amounts of serum containing BEM ( $1 \mathrm{ml}$ per bottle), counted in a haemocytometer and their number was expressed in cells $/ \mathrm{ml}$. Viable cell counts were determined by the trypan blue exclusion method. The number of cells from samples kept in cultures till the last interval was expressed as saturation density $\left(\mathrm{cell} / \mathrm{cm}^{2}\right)$ and was further used for estimation of doubling time of culture population ( Patters on 1979). 
Staining technique

The cell grown in $60 \mathrm{~mm}$ FALCON Petri dishes for $48 \mathrm{hrs}$ were rinsed with phosphate buffer (pH 7.2), fixed with methanol and stained with Giemsa according to the method described by Fre sh ne y (1987).

Cell metabolism and cytotoxicity studies

The cells cultivated in the presence of PRGF and cytostatics as described in this section were trypsinized and the number of cells was determined. One portion of cell suspensions was used for estimation of protein content by Lowry method (Freshney 1987). Another part of suspension was then frozen and thawed three times at $70^{\circ} \mathrm{C}$ to disrupt cells and the nucleic acid were extracted using procedure described by Munro and Fleck (1966). The DNA content of the extract was estimated by a shortened diphenylamine method (Gendimenico et al. 1988). The media of all samples were clarified by low-speed centrifugation (15 min at 180 r.p.m) and tested for glucose uptake (Dahlquist 1964), as well as for lactate (Horost et al. 1974) and ammonia (Bolleter et al. 1961) production. The probable percentage of conversion of glucose into lactate was calculated according to the formula:

lactate production

glucose consumption $\times 2 \times 100$.

\section{Results}

The effect of PRGF and cytostatics on transformed phenotype of Hep-2 cells

PRGF itself, when present in the medium of cultured Hep-2 cells supressed the appearance of transformed phenotype (,,criss-cross“ pattern of growth) confirming previously obtained data (Gola is et al. 1990; Gol a is et al. 1992), see Plate XI., Fig.1a,b.

An interesting phenomenon was observed, when PRGF was combined with 11 out of 12 cytostatics. These cytostatics interfered with the transformed phenotype repressing activity of PRGF, so that the cells retained the appearance of transformed control cells (Plate XI., Fig. 1c, Plate XII., Fig. 1d).This undesirable interference was not observed, when MTX was used in combination with PRGF (Plate XII., Fig.le).

Similarly, when PRGF and each of 11 cytostatics were present in soft agar, the colonies of transformed cells appeared having the size resembling that of the control cells. On the other hand, a supression of the formation of colonies was observed, when this agar contained either PRGF alone or combined with MTX. The effect of cytostatics without PRGF on the formation of colonies was not studied.

\section{Growth characteristics of cells treated with PRGF and cytostatics}

All cytostatics, when present in the medium decreased the saturation density of Hep-2 cells to about $55-80 \%$ and brought about a $15-40 \%$ prolongation of their doubling time as compared to the control cells cultured in intact medium. Both these effect were diminished when 11 cytostatics (with the exception of MTX) were added to the cultures simultaneously with PRGF. In this case, the decrease of the saturation density, as well as the doubling time prolongation were slightly reduced (see Table 2 ).

Even though MTX showed most marked effect on the cell growth, its effect was not significantly influenced by PRGF. PRGF, present without cytostatics slightly stimulated the growth of Hep-2 cells. Subsequently, 6-TG, E- 4IB and MTX were chosen for more detailed studies. As follows from the growth curves depicted in Fig. 2, PRGF in spite of this transformed phenotype repressing activity enhanced the growth of Hep-2 cells and the same did in cells cultivated in the presence of 6-TG and E-4 IB (Fig. 2 a,b), however, in this case, as already mentioned (see Fig.1), its ability to repress transformation was lost. Different from other cytostatics, the inhibition of cell growth by MTX was not significatly influenced by PRGF (Fig. 2). 
Table 2

Saturation densities and doubling times of Hep -2 cells cultivated in the presence of PRGF and cytostatics

\begin{tabular}{|c|c|c|}
\hline Cytostatics & $\begin{array}{l}\text { Saturation density } \\
\text { cells } \times 10^{3} / \mathrm{cm}^{2}\end{array}$ & $\begin{array}{c}\text { Doubling time } \\
\text { hrs }\end{array}$ \\
\hline Control & $52 \pm 1.5$ & 57 \\
\hline PRGF & $64 \pm 1.7$ & 49 \\
\hline 6-TG & $36 \pm 1.9$ & 75 \\
\hline 6-TG + PRGF & $40 \pm 1.0$ & 69 \\
\hline E-4 IB & $34 \pm 1.7$ & 80 \\
\hline E-4 IB + PRGF & $38 \pm 1.8$ & 72 \\
\hline MTX & $28 \pm 1.7$ & 98 \\
\hline $\mathrm{MTX}+\mathrm{PRGF}$ & $29 \pm 1.6$ & 94 \\
\hline Carboplatin & $37 \pm 1.2$ & 74 \\
\hline Carboplatin + PRGF & $41 \pm 1.6$ & 67 \\
\hline Doxorubicin & $35 \pm 1.1$ & 78 \\
\hline Doxorubicin + PRGF & $42 \pm 1.3$ & 66 \\
\hline Ifosfamid & $38 \pm 1.4$ & 72 \\
\hline Ifosfamid + PRGF & $42 \pm 1.1$ & 66 \\
\hline Uromitexan & $37 \pm 1.7$ & 74 \\
\hline Uromitexan + PRGF & $42 \pm 0.8$ & 66 \\
\hline Taxol & $32 \pm 1.8$ & 85 \\
\hline Taxol + PRGF & $35 \pm 1.3$ & 78 \\
\hline Fluorouracil & $36 \pm 1.8$ & 75 \\
\hline Fluorouracil + PRGF & $40 \pm 1.1$ & 69 \\
\hline Cytarabine & $37 \pm 1.5$ & 74 \\
\hline Cytarabine + PRGF & $40 \pm 1.1$ & 69 \\
\hline Vincristine & $31 \pm 1.2$ & 87 \\
\hline Vincristine + PRGF & $34 \pm 1.5$ & 80 \\
\hline Etoposide & $36 \pm 1.8$ & 75 \\
\hline Etoposide + PRGF & $40 \pm 0.9$ & 69 \\
\hline
\end{tabular}

Cells were trypsinized and counted after entire $120 \mathrm{hrs}$ cultivation. Mean values taken from 5 repeated experiments.

\section{Estimation of metabolic variables}

To characterize the cytostatic and cytotoxic effect of 6-TG, E-4 IB and MTX combined with PRGF in greater detail, the changes in the amount of DNA and proteins, as well as those in the glucose and glutamine metabolism, resulting from exposure of the cells to these drugs were measured.

The treatment of cells with 6-TG and E-4 IB was accompanied with the increase in the cellular DNA content and PRGF interfered with this effect. On the other hand, MTXinduced decrease of DNA content. PRGF alone, reduced the amount of DNA in Hep-2 cells to about $60 \%$ (Fig. 3a).

A considerable increase in protein content was demonstrated after treatment of cells with E-4 IB and MTX. PRGF was able to abolish this effect when acted along with E-4 IB however, it was not able to influence the protein increase in MTX-treated cells. Less marked 
Fig. 2a

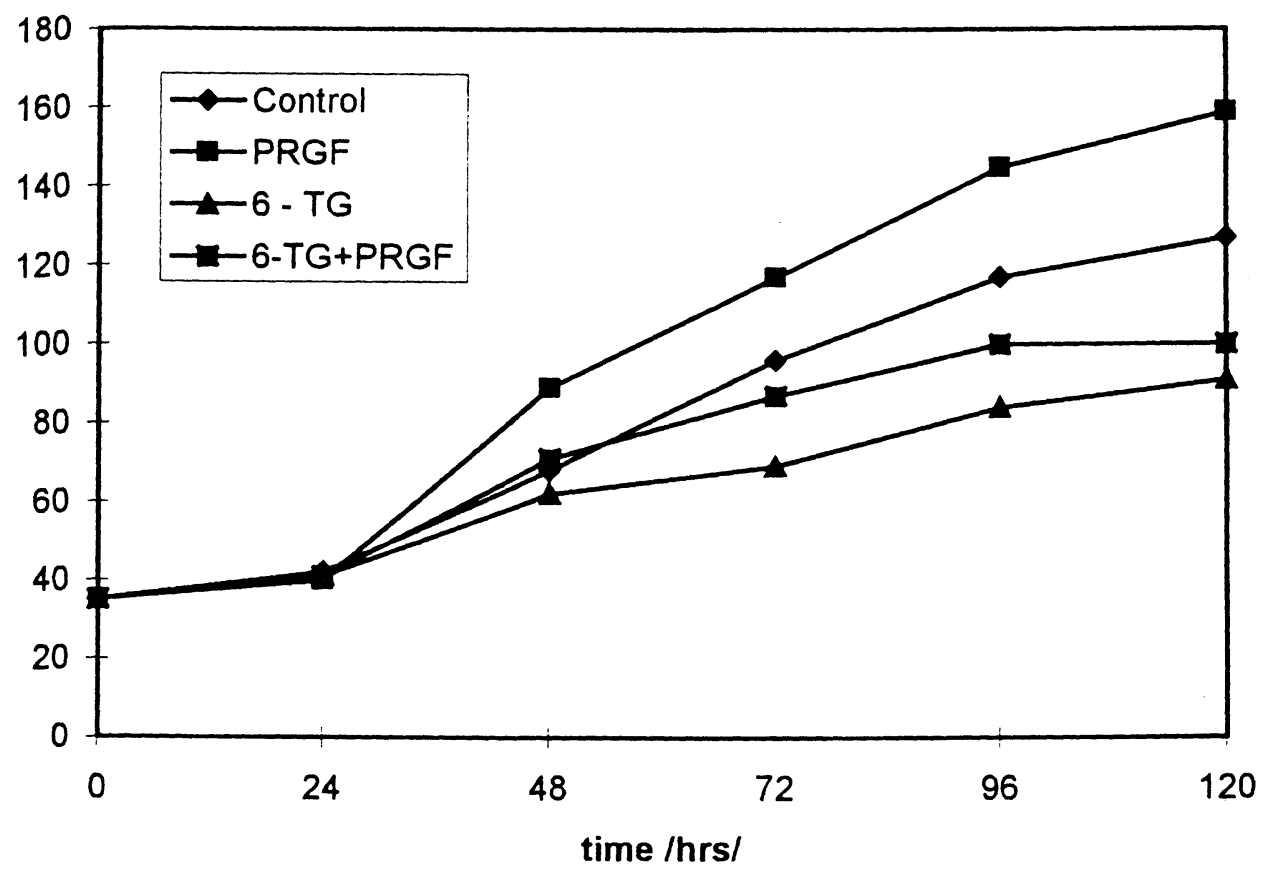

Fig. 2b

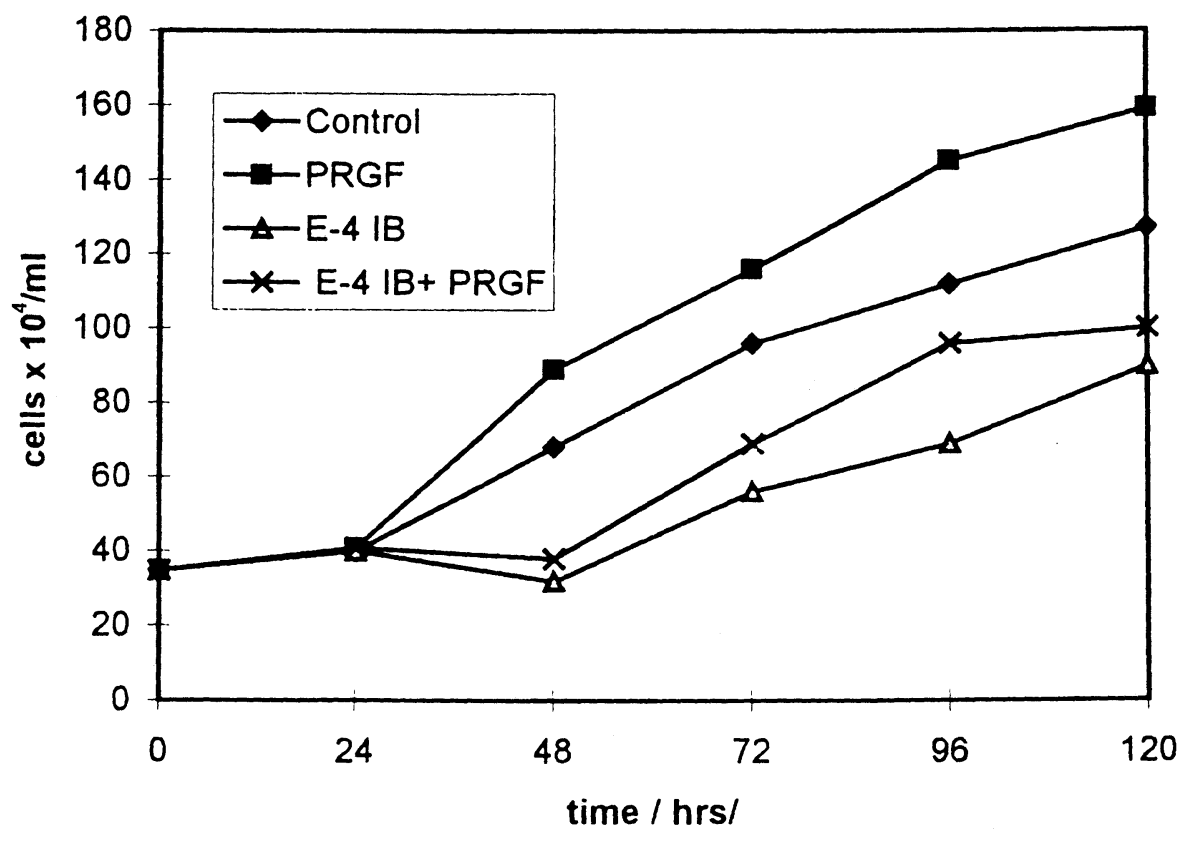


Fig. $2 c$

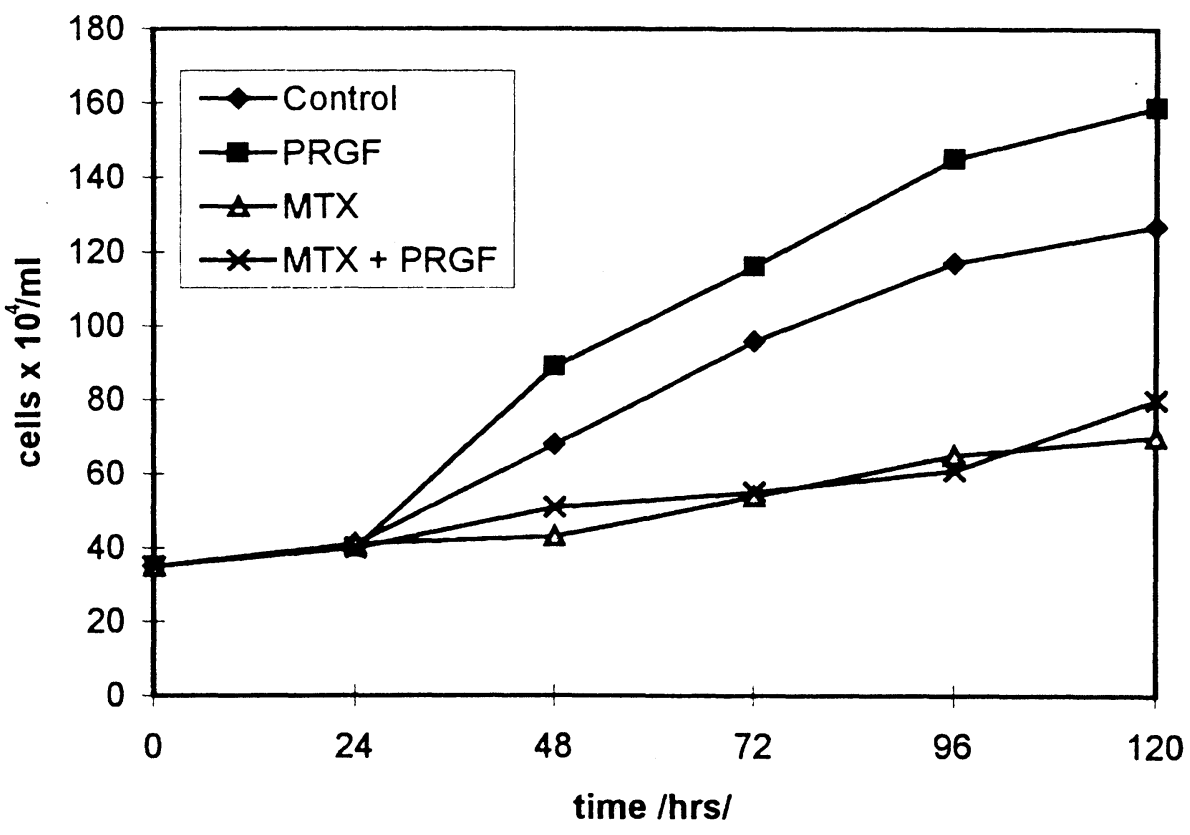

increase in protein content, which could be similarly abolished by PRGF was demonstrated in 6-TG treated cells. PRGF, present in medium without cytostatics had no effect on protein synthesis (Fig. 3b).

Fig. 3a

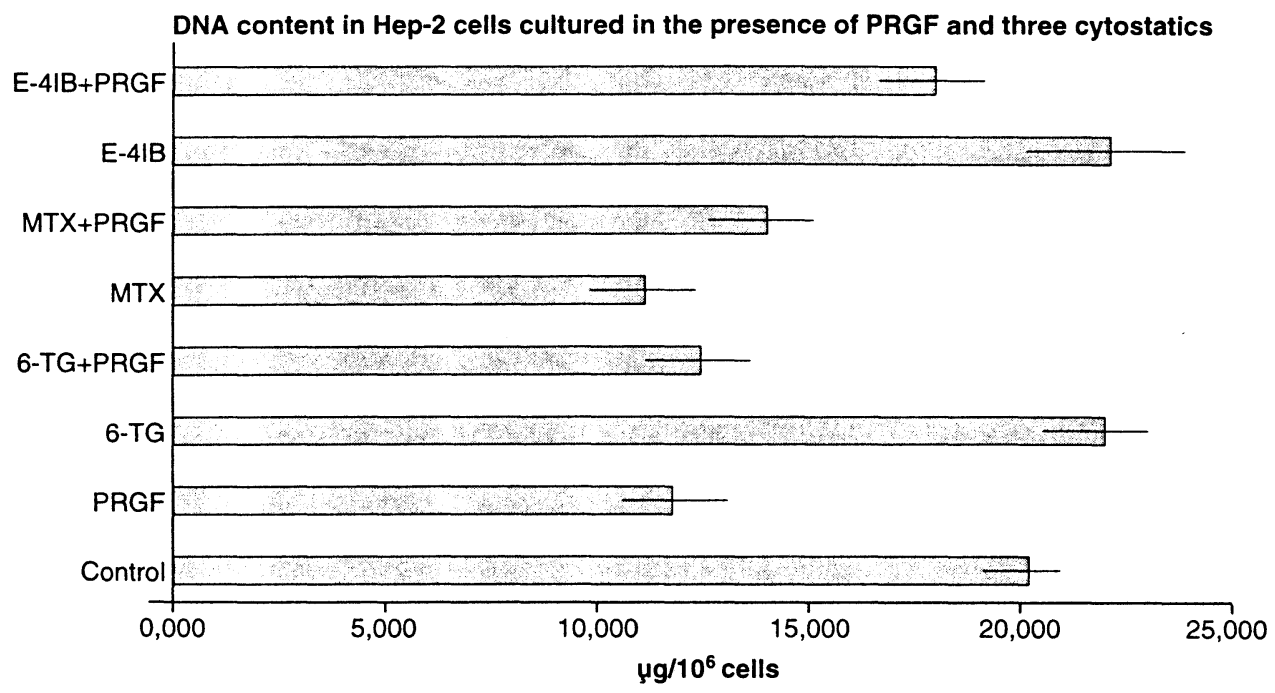


Fig. 3b

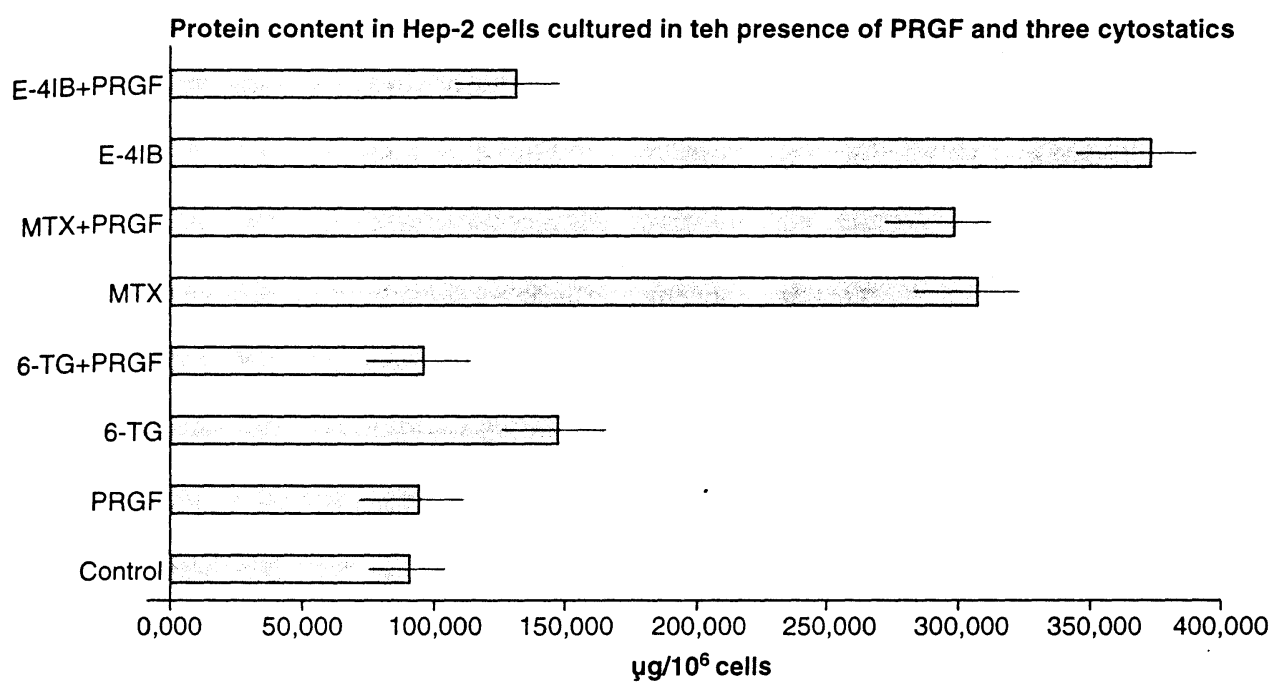

Cells treated by MTX used about $50 \%$ less glucose from the culturing medium during the whole incubation period than control cells, whereas glucose uptake in E-4 IB treated cells was reduced only to about $80 \%$ or was not significantly changed in 6-TG treated cells. PRGF alone, or combined with these three cytostatics did not substantially affect the glucose consumption (Fig. 4). Lactate production, as well as conversion of glucose into lactate are

Fig. 4

Concentration of glucose in the medium of Hep-2 cells cultured in the presence of PRGF and cytostatics

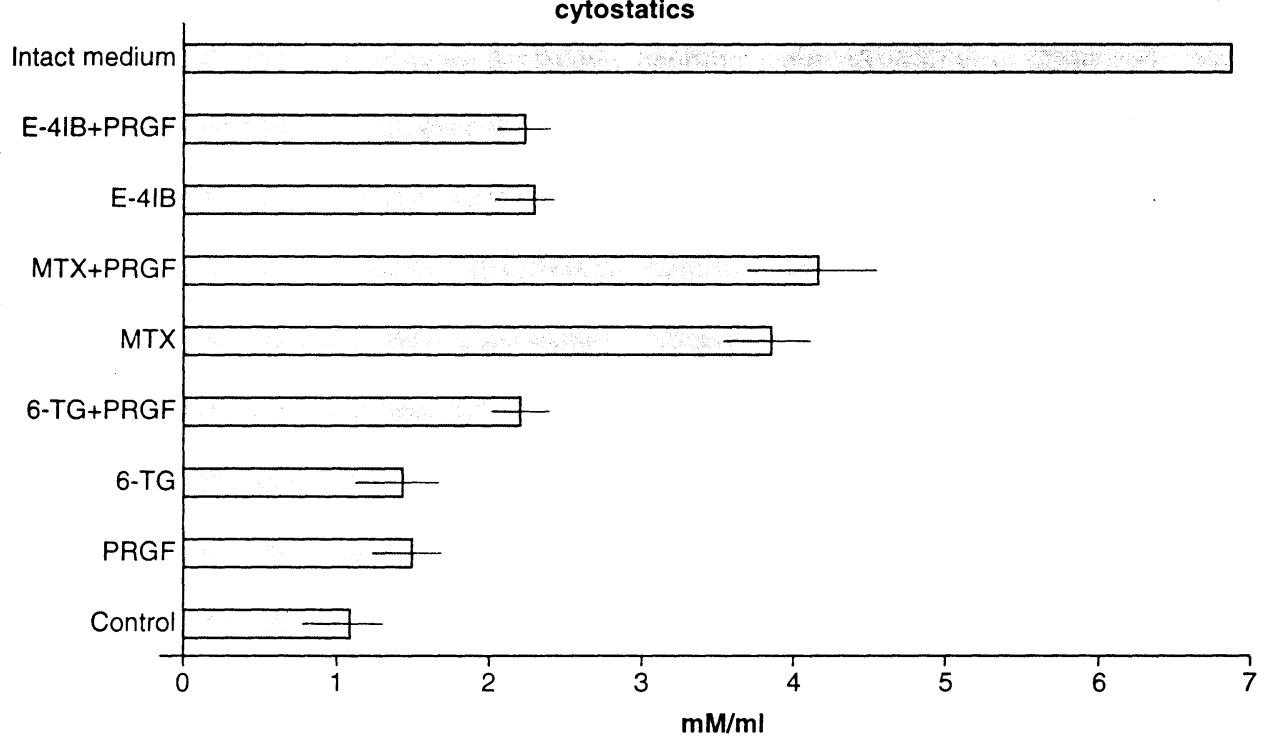


summarized in Table 3. As follows from Fig. 5 where the lactate concentration was expressed in $\mathrm{mM} / 10^{6}$ cells, MTX enhanced markedly the lactate production and a similar but less marked enhancement was observed in 6-TG and E-4 IB treated cells. PRGF retained this effect, however not influencing the lactate production in cells without cytostatics. Similar results were obtained when ammonia production was measured (see Fig. 6).

Fig. 5

Lactate concentration in Hep-2 cells

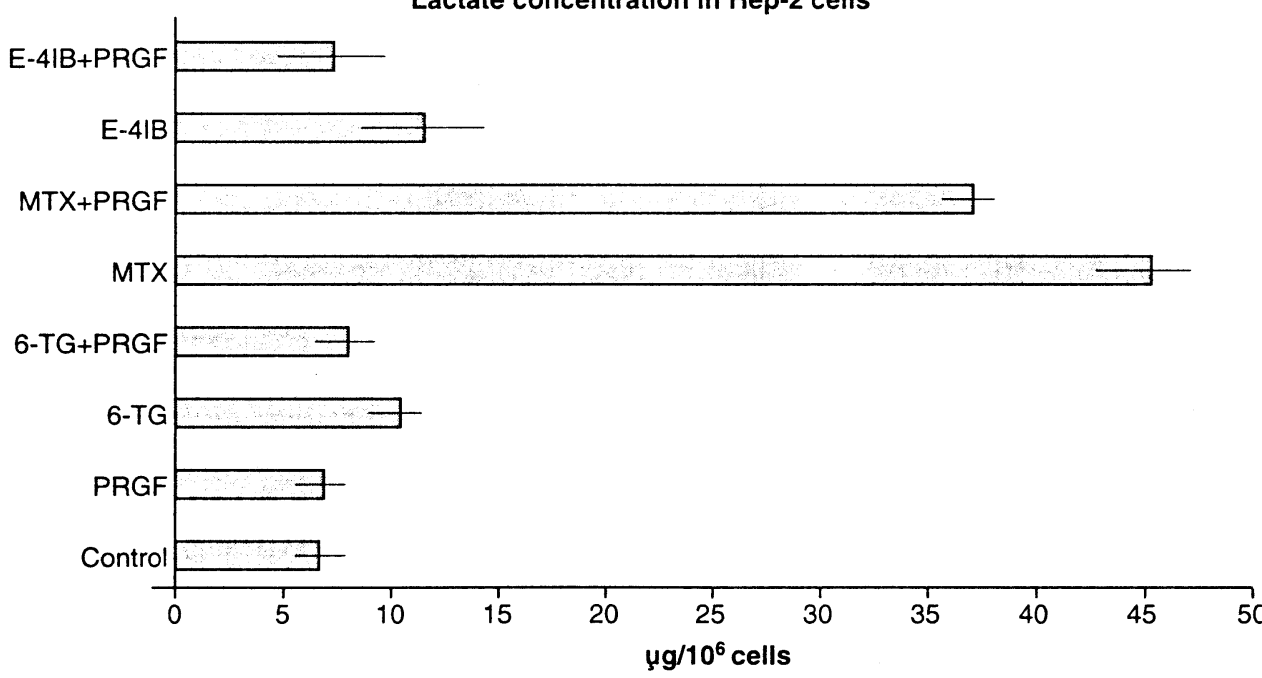

Fig. 6

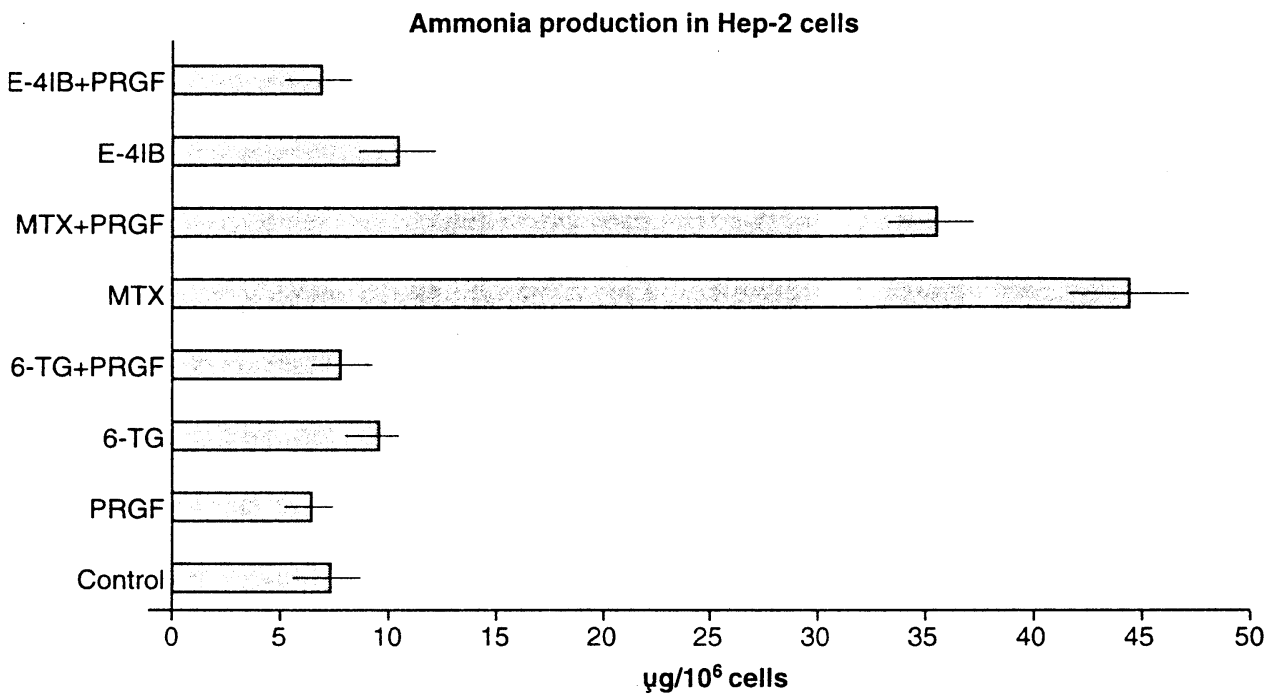


Table 3

Glucose metabolism of $\mathrm{Hep}-2$ cells cultivated in the presence of PRGF and three cytostatics

\begin{tabular}{|l|ccc|}
\cline { 2 - 4 } \multicolumn{1}{c|}{} & $\begin{array}{c}\text { Glucose } \\
\text { consumption }\end{array}$ & $\begin{array}{c}\text { Lactate } \\
\text { production }\end{array}$ & $\begin{array}{c}\text { Conversion of glucose } \\
\text { into lactate }\end{array}$ \\
\cline { 2 - 4 } & $\mathrm{mM} / \mathrm{ml}$ & $\mathrm{mM} / \mathrm{ml}$ & $\%$ \\
\hline Control & $5.8 \pm 0.3$ & $8.6 \pm 0.3$ & 74.0 \\
\hline PRGF & $5.5 \pm 0.2$ & $10.9 \pm 0.2$ & 100.5 \\
\hline $6-$ TG & $5.5 \pm 0.4$ & $9.5 \pm 0.3$ & 87.1 \\
\hline $6-$ TG + PRGF & $4.7 \pm 0.2$ & $8.0 \pm 0.2$ & 85.2 \\
\hline MTX & $3.1 \pm 0.3$ & $16.6 \pm 0.2$ & 267.0 \\
\hline MTX + PRGF & $2.7 \pm 0.1$ & $16.4 \pm 0.3$ & 292.0 \\
\hline E-4 IB & $4.6 \pm 0.2$ & $7.3 \pm 0.2$ & 79.1 \\
\hline E-4 IB + PRGF & $4.7 \pm 0.3$ & $5.7 \pm 0.4$ & 61.4 \\
\hline
\end{tabular}

\section{Discusssion}

An undesirable mutual interaction was observed, when PRGF was combined with 11 out of 12 cytostatics and added to tumour Hep- 2 cells. These cytostatics reversed the ability of PRGF to repress the transformed phenotype of cells, and on the other hand, PRGF decreased their cytostatic and cytotoxic effect.

An increase in DNA and protein synthesis is often observed after treatment of cells with some cytostatic drugs especialy with those which interfere with the synthesis of nucleic acids and proteins as a counsequence of unbalanced cell growth (Cohen and Studzinski 1967; Horáková et al. 1974; Ross 1983; Savwicka et al. 1986; Horáková etal. 1988). Both 6-TG and E-4 IB increased the synthesis of DNA and proteins in Hep-2 cells confirming previously obtained data (Tidd et al. 1972; Horáková et al. 1978; Ho rá k o vá et al. 1993) and PRGF repaired these changes. Similarly, the increase in lactate and ammonia production brought about by 6-TG and E-4 IB treatment was supressed by PRGF. At present we have no explanation for these fimdings. This mutual relationship between PRGF and 11 cytostatics has to be studied at molecular level.

PRGF, present in the medium of cultured Hep-2 cells without cytostatics did not significantly influence the lactate and ammonia production, or the protein synthesis. However, it decreased the DNA content as compared to that of control cells cultivated without PRGF and cytostatics, in spite of its growth stimulating activity (Fig. 2). About $40 \%$ decrease in DNA content (see Fig. 3) might be due to the loss of the transformed phenotype of Hep-2 cells mediated by PRGF.

The results obtained with MTX were markedly different from those obtained with 6-TG, E-4 IB and other cytostatics. MTX was shown not to interfere with the transformed phenotype repressing activity of PRGF and on the other hand, its cytostatic effect in Hep-2 cells was not impaired by PRGF. As different from 6-TG and E-4 IB, DNA content in MTX treated cells was lower as compared to controls, which may be due to purineless and thymidineless state in cells owing to the depletion of tetrahydrofolates by inhibition of dihydrofolate reductase (Fridland 1974; Johnston et al. 1995). This effect was slightly repaired by PRGF. Elevated ammonia production in MTX treated cells might be 
due to the reduced glucose uptake seen in Fig. 4, which might lead to increased glutamine utilization (Butler and Spier 1984; Lanks 1987). In spite of the reduced glucose consumption, the conversion of glucose to lactate was considerably enhanced (up to 260\%). Thus, in the presence of MTX some other carbon compounds probably lipids (Geyer, 1967), or amino acids ( $\mathrm{Zi}$ el ke et al. 1978; Horák ová et al. 1989) might be converted into lactate. The values of ammonia and lactate cocentrations were lower, although still considerably remote from the control levels in non-treated Hep-2 cells, when MTX was combined with PRGF (see Fig. 5 and 6).

As follows from the results presented in this paper, MTX along with PRGF might represent an appropriate combination for the treatment of cancerogenic cells. As our in vitro studies showed, the cytostatic effect of MTX may be deapened by the loss of the transformed phenotype caused by PRGF, which may moreover slightly reduce the cytotoxic changes brought about by MTX. However, there is one problem concerning PRGF, which might hinder its successfull application to cancer. In addition to the transformed phenotype repressing activity, PRGF transforms normal, non-transformed cells ( $\mathrm{G}$ o l a is et al. 1990; Dušinská et al. 1994). Althougth the oncogenicity of PRGF in organism was not demonstrated as yet, PRGF was only shown to facilitate the growth and postnatal development of newborn mice and rats, when administered subcutaneously without inducing tumours or pathological changes (Csabayová et al. 1995), it would be still riskfull to use PRGF for the treatment of tumours. It appears to be a general feature of most (if not all) herpesviruses to code under certain culture conditions for growth factors as shown in our last study ( $\mathrm{G}$ a šperík et al. 1996). Some of them could be divided into two, some other into three active components. Especialy the „middle“ B component of the threecomponent factors might be of value for our purposes. These components are devoid of the transforming activity possessing only an ability to repress the transformed phenotype ( $\mathrm{G}$ a š pe rík et al. 1996). Thus these components might become appropriate candidates for a successfull application to cancer e.g. combined with MTX. This will be an aim of our future studies.

\section{Vplyv rastového faktora vírusu pseudorabies (PRGF) a rôznych cytostatík na nádorové Hep-2 bunky in vitro}

Jednou $\mathrm{z}$ aktivít rastového faktora vírusu pseudorabies (PRGF) je schopnost menit transformačný fenotyp pestovaných nádorových buniek na normálne. Táto aktivita PRGF sa študovala v kombinácií $s$ antiproliferatívnou aktivitou rôznych cytostatík. K nežiadúcim výsledkom sme dospeli u 11 z 12 cytostatík. Tieto potlačovali schopnost PRGF menit transformačný fenotyp Hep-2 buniek, znižovali rast buniek a mali vplyv aj na ich metabolizmus (obsah DNA a bielkovín, spotrebu glukózy a tvorbu kyseliny mliečnej a amoniaku) $\mathrm{v}$ porovnaní $s$ neovplyvnenou kontrolnou skupinou. Tento vplyv nebol pozorovaný pri kultivácii buniek Hep-2 v prítomnosti PRGF a Metotrexatu. V tomto prípade bola pozorovaná aj schopnosí transformovat nádorové bunky ako aj inhibícia rastu buniek. Diskutovaná je možnost použitia kombinácie PRGF a Metotrexatu pri štúdiu nádorov.

\section{Acknowledgement}

This work was supported in part by Grant Agency for Science (Grant No. 2/1245).

\section{References}

BOLLETER, W. T., BUSHMANN, C. J., TILWELL, P.-W. 1961: Spectrophotometric determination of ammonia as indophenol. Anal.Chem. 33: 592-601 
BUTLER, M., SPIER, R. E. 1984: The effect of glutamine utilization and ammonia production on the growth of BHK cells in microcarriers cultures. J. Biotechnol. 1:187-196

COHEN, L. S., STUDZINSKI, G. P. 1967: Correlation between cell enlargement and nucleic acid and protein content of HeLa cells in unbalanced growth produced by inhibitors of DNA synthesis. J. Cell Physiol. 69: 739-745

CSABAYOVÁ, M., LEŠKO, J., DUŠINSKÁ, M., GAŠPERIK, J., GOLAIS, F. 1995: Pseudorabies virus growth factor (PRGF) facilitates the growth and postnatal development of mice and rats. Acta vet. Brno, 64:249-255

DAHLQUIST, A. 1964: Method for assay of intestinal dissaccharides. Anal. Biochem. 7:18-23

DUŠINSKÁ, M., LEŠKO, J., GOLAIS, F., SLAMEÑOVÁ, D. 1994: Morphological transformation of syrian hamster embryo cells by pseudorabies virus related growth factor. Cancer Lett. 79:125-130

FLOCH, L., KOVÁĆ, S. 1975: Synthesis and properties of Alkyl Isothiocyanatocarboxylates. Coll. Czechoslov. Chem. Commun. 40:2845-2854

FRESHNEY, R. I. 1988: Culture of animal cells. A manual of basic technique. Allan R. Liss, Inc., New York.

FRIDLAND, A. 1974: Effect of methotrexate on deoxyribonucleic pools and DNA synthesis in human lymphocytic cells. Cancer Res. 34:1883-1888

GAŠPERÍK, J., LEŠKO J., GOLAIS F. 1996: Growth factors encoded by various herpesviruses can be resolved in two or in three components. Biol. Zentbl. 115:71-77

GENDIMENICO, G. J., P. L. BOUQUIN, P. L., TRAMPOSCH, K. M. 1988: Diphenylamine- colorimetric method for DNA assay: A shortened procedure by incubating samples at $50 \mathrm{oC}$. Anal. Biochem. 173: 45-48

GEYER, R. P. 1988: Uptake and retention of fatty acids by tissue culture cells. In: G.H. Rothblatt and D. Kritschevsky (Eds), Symposium Monogr. Vol. 6, Wistar Institute Press, pp. 85-90

GOLAIS, F., LEŠKO, J., HILLEROVÁ, A., KOLCUNOVÁ, A., SABO, A. 1990: Putative virus-encoded growth factor in a crude extract of pseudorabies virus infected and transformed human cells. Biol. Zentbl. 109: 481-487

GOLAIS, F., CSABAYOVÁ, M., LEŠKO, J., BYSTRICKÁ, M., SABO, A. 1992: Herpes simplex virus type 2 and pseudorabies virus associated growth factors and their role in the latency in vitro. Acta virol. 36: 505-515

HAYFLICK, L., MOORHEAD, P. S. 1961 : The serial cultivation if diploid cell strains. Exp. cell Res. 25: 585621

HORÁKOVÁ, K., NAVAROVÁ, J., PATERSON, A. R. P. 1974: The delayed cytotoxic effect of 6mercaptopurine. Characterization of the unbalanced growth of HeLa cells produced by 6-mercaptopurine. Biochem. biophys. Acta 366: $333-340$

HORÁKOVÁ, K., CZÍKOVÁ, S., KERNÁČOVÁ, B. 1978: Suitability of different quantitative methods for determination of cytotoxic activity of agents in cell cultures. Neoplasma 25: 309-318

HORÁKOVÁ K., JANTOVÁ, S., FORGÁCS,A., PERÉNYI, T., LUKÁČOVÁ, D. 1988: The study of cytotoxic effect of benfluron. Neoplasma 35: 169-176

HORÁKOVÁ, K., VALENTOVÁ, N., CHORVÁTH, B., PERÉNYI, T., FORGÁCS, A. 1989: Study of metabolism and growth limitation of human leukemia cell lines. Neoplasma 36: 287-295

HORÁKOVÁ, K., JANTOVÁ, S., STREDOČANSKÝ, M., NOVOTNÁ, L., FLOCH, L. 1993: Ethyl-4isothiocyanatobutanoate-antiproliferative activity in vitro and in vivo. Anti-Cancer Drugs 4: 369-375

HOROST, H., GUTTMAN, N. N., WAHLEFELD, A. 1974: Determination with LDH and NAD.In:H.V.Barsmayer (Ed.), Methods of enzyme analysis 3, Academic Press, New York, pp. 1465-1469

JOHNSTON, J. A., JOHNSON, E. S., WALLER, P. R. H. VARSHAVSKY, A. 1995 : Methotrexate inhibits proteolysis of dihydrofolate reductase by the $\mathrm{N}$-end rule pathway. J. Biol. Chem. 270: 8172-8178

LANKS, K. W. 1987: End products of glucose and glutamine metabolism by L 929 cells. J. Biol. Chem. 262: $10093-$ 10097

MUNRO, H. N., FLECK, A. 1966: Recent developments in the measurement of nucleic acids in biological materials. Analyst 91: 78-88

PATTERSON, M. K. Jr. 1979: Measurement of growth and viability of cells in culture. In: S. P. Colowick and N. O. Kaplan (Eds), Methods in Enzymology, Vol.58, Academic Press, Inc., New York, p. 150

ROSS, D. W. 1983: Unbalenced growth and increased protein synthesis induced by chemotherapeutic agents. Blood cells, 9: 57-68

SAWICKA, J., GOLOS, B., MALEC, J. 1986: Mechanism of unbalanced growth induced cell damage. II. A probable relationship between unbalanced growth, DNA breakage and cell death. Chem-Biol. Interact. 146: 4755

TIDD, D. M., KIM, K., HORÁKOVÁ, K., MORIWAKI, A., PATTERSON, A. R. P. 1972: A delayed cytotoxic reaction for 6- mercaptopurine. Cancer Res. 32: 317-322

ZIELKE, H. R., OZAND, P. T., TILDON, J. T., SERDALION, D. A., CORUBLATH, M. 1978: Reciprocal regulation of glucose and glutamine utilization by culture human diploid fibroblasts. J.Cell Physiol. 95: 41-48 
Address for correspondence:

Doc. RNDr. F. Golais, CSc.

Department of Microbiology and Virology

Faculty of Natural Sciences, Comenius University

Mlynská Dolina B-2

84215 Bratislava

Slovak Republic

Phone: (421) 73783348 
Plate XI.

Kocáková P. et al.: A combined... pp. 159-169

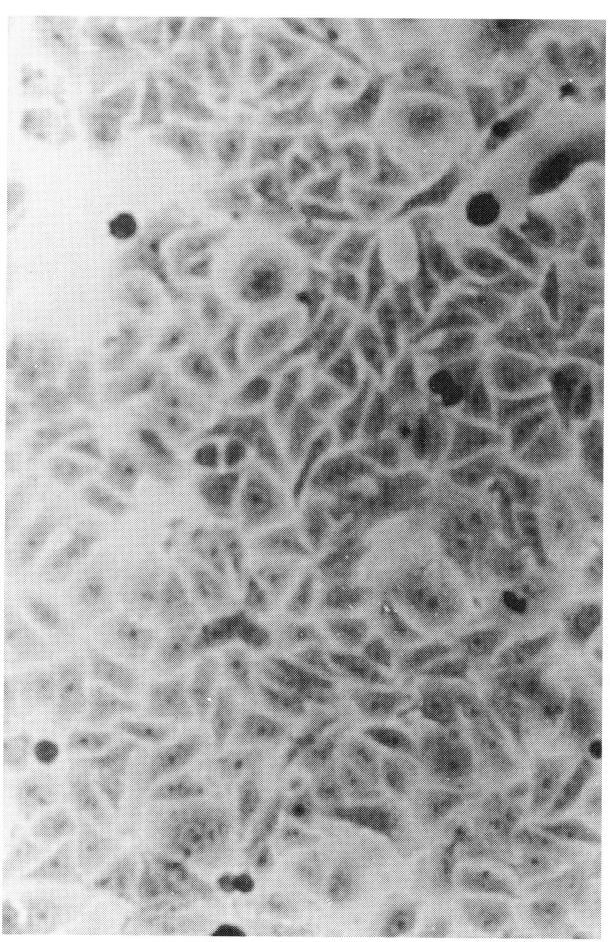

Fig.1a: Control Hep-2 cells $(\times 400)$

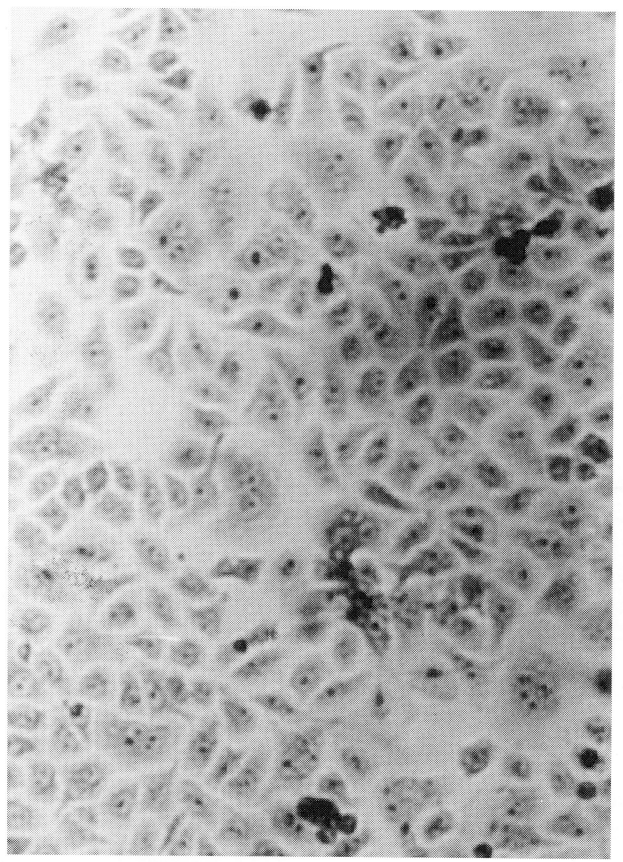

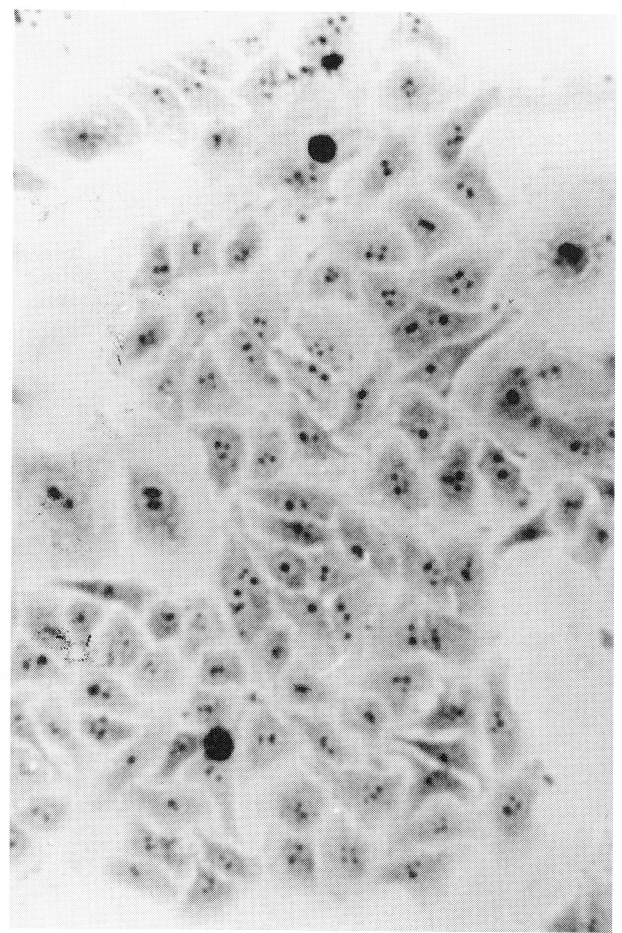

Fig.1b: Hep-2 cells cultivated in the presence of PRGF $(\times 400)$
Fig.1c: Hep-2 cells cultivated in the presence of E-4 IB $(\times 400)$ 
Plate XII.

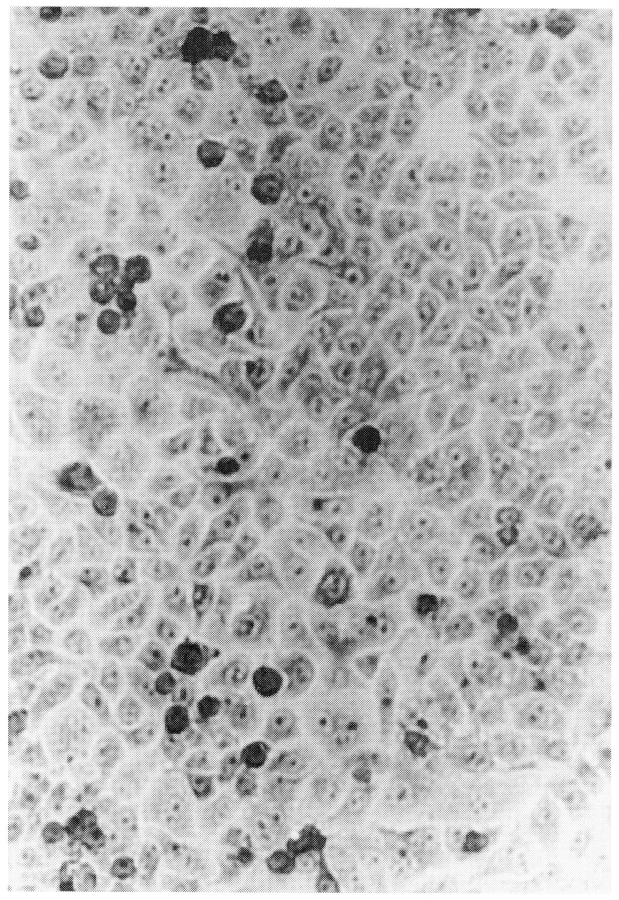

Fig.1d: Hep-2 cells cultivated in the presence of E-4IB and PRGF $(\times 400)$

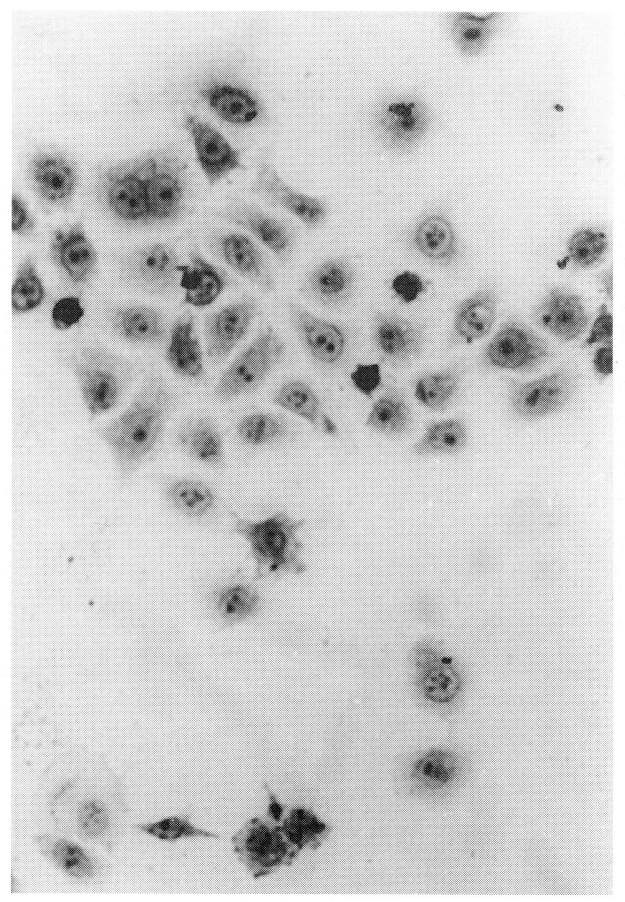

Fig.1e: Hep-2 cells cultivated in the presence of MTX and PRGF $(\times 450)$ 